\title{
Editorial
}

\section{When is a data base an automobile?}

Although I don't get to Europe as often as I used to, I am still bemused by the xenophobic comments and programs brought to my attention when I do. Largely, they are directed at non-European data bases and systems. I hear talk of "reversing the information flow", and presumably reversing the cash flow as well.

I hear about "uniquely European needs" and "preemptive marketing" and so on and so forth. In my humble way, I usually smile enigmatically and offer some soothing comment or other.

Recently (probably at IOLIM), I got a sense of déjà vu. I had heard all of this before! But where? Then I realized that what I remembered was an American whine, and it was about cars.

"You-know-who" is flooding the American market with their miserable (high quality), funny-looking (fuel-efficient) cars. What are we going to do about it? Set up quota's, send a trade mission, establish a Congressional committee. Result? Lose significant parts of the market.

Then some heretic figured out that it would be a good idea to make a competitive car. Or, make a deal and buy some of their cars and combine their product with our distribution and sales organization. It also occurs to me that "you-know-who" doesn't make the best of every kind of car. What about the kind that we make best? ISU readers can install additional approaches for themselves.

The analogy is not perfect, but it will serve, and hopefully provoke a response.

These pages are open for that purpose.

A.W. Elias 